\title{
“Alma mater Studiorum": příklad dobré praxe ve vzdělávání učitelů
}

\section{Kateřina Jančaříková}

\section{Envigogika 13 ( 1) - I nspirace / I nspiration}

Publikováno / Published 10. 8. 2018

DOI : $\underline{10.14712 / 18023061.573}$

\begin{abstract}
Abstrakt
Projekt Alma Mater Studiorum, který byl realizován v letech 2010-2012, se zaměřuje na další vzdělávání učitelů a pedagogických pracovníků Středočeského kraje v oblasti EVVO (environmentální výchova, vzdělávání a osvěta). $V$ rámci projektu vytvořili odborníci (lektoři) z různých pracovišt́ převážně Univerzity Karlovy 22 kurzů (15 seminářủ a 7 exkurzí), které byly následně akreditovány MŠMT a ke kterým byly připraveny informační brožurky. Celkově bylo projektem podpořeno více 961 účastníků z řad cílové skupiny. $V$ tomto př́spěvku popíšeme proces tvorby seminářu a exkurzí (počínaje výzkumným hledáním témat - "bílých míst“ české EVVO, konče výběrem lektorů) a podělíme se s nabytými zkušenostmi. Ve výzkumné části přispěvku budeme hodnotit několik vybraných otázek z dotazníku, který účastníci vyplňovali.
\end{abstract}

\section{Klíčová slova}

Celoživotní vzdělávání; environmentální výchova; semináře; exkurze

\begin{abstract}
Alma Mater Studiorum project was conducted in the years 2010-2012. The project was focused on training teachers in environmental education offered 15 seminars and 7 excursions, all accredited by Ministry of Education. Lecturers to their respective programs had written publications. The activities were attended by 961 participants. In this paper we present the objectives and the basis for the preparations of seminars and excursions and the experience of the organizers and lecturers. The article includes an evaluation based on the questionnaire responses generated by the participants during in the project.
\end{abstract}

\section{Key words}

Life-long learning; environmental education; seminars; excursions 


\section{Úvod}

Projekt Alma Mater Studiorum (CZ.1.07/1.3.04/02.0010), ukončený před několika lety, je stále dobrým př́íladem dalšího vzdělávání učitelů ve Středočeském kraji $v$ oblasti environmentální výchovy a vzdělávání. Tento příspěvek má přispět radou dalším žadatelům a řešitelům projektů celoživotního vzdělávání pedagogických pracovníků (ukazuje, jak podobný projekt plánovat, vést, jak získat účastníky a jak uspokojit jejich potřeby atd.). Informace zde prezentované byly získány vyhodnocením dotazníků, které byly zadávány po semináŕích a exkurzích účastníkům kurzů (celkem se jedná o 961 podpořených osob a 757 správně vyplněných a vyhodnocených dotazníků), a také rozhovory s aktéry (lektory, účastníky a manažery projektu). $V$ dotaznících byly položeny také výzkumné otázky z oboru environmentální výchovy. J ejich zpracování nebude (vzhledem k omezenému rozsahu) zahrnuto do tohoto přispěvku. Autorka příspěvku pracovala $v$ projektu jako odborný garant seminářù.

\section{Teoretická část}

Pojem celoživotní vzdělávání známe od 70. let 20. stol. (Bočková, 2000). Celoživotní vzdělávání je členskými státy Evropské unie považováno za důležitý faktor růstu produktivity a konkurenceschopnosti ekonomiky, a následně je podporováno ze strukturálních fondů.

Celoživotní vzdělávání je založeno na potřebě permanentní kultivace člověka a jeho rozvoje. Podílí se na socializaci člověka a je hlavním nástrojem vpravování se do kultury přislušné společnosti (Bočková, 2000). Vzdělávání učitelů je specifické druhotným dopadem na žáky a studenty. Stručně řečeno: bez celoživotního, soustavného a kvalitního vzdělávání učitelů nemůžeme mít kvalitní školství.

J. Kohnová chápe pojem dalšího vzdělávání pedagogických pracovníků jako dlouhodobý institucionálně koordinovaný proces odehrávající se $v$ průběhu celé učitelovy profesionální dráhy, kdy se učitelé vzdělávají pod dohledem dalších osob (školitelů). Po celou tuto dobu jsou rozvíjeny nejen profesní, ale také osobnostní kompetence učitele (Kohnová, 2004).

V České republice je celoživotní vzdělávání, včetně celoživotního vzdělávání učitelů a pedagogických pracovníků, ve fázi rozvoje. V roce 2006 byla Česká republika mezi 25 státy Evropské unie začleněnými do dalšího vzdělávání až na 21. místě (Palán, 2007). Následně MŠMT vydalo pro Českou republiku publikaci Strategie celoživotního učení ČR. Ta byla schválena vládním usnesením č. 761/2007. V této publikaci jsou vytyčeny postupy a úkoly, které by měly vést ke zlepšení stávající situace. V Implementačním plánu Strategie celoživotního učení (2008) MŠMT spolu se sociálními partnery vytyčilo postup realizace celoživotního učení v České republice. V lednu 2010 Vláda ČR schválila Zprávu o plnění Implementačního plánu Strategie celoživotního učení za rok 2009. V ní se hodnotí stav a průběh prací zavádění prvků celoživotního vzdělávání do praxe. Krátce se o celoživotním učení zmiňuje i materiál Prưvodce dalším vzděláváním (leden 2010) - zaměřený na aktivity MŠMT v této oblasti. Právě díky této snaze EU a potažmo MŠMT České republiky mohl být projekt Alma Mater Studiorum realizován. 


\section{Použité metody, respondenti, vyhodnocování}

Pro získání dat prezentovaných v tomto příspěvku bylo použito dotazníkové šetření. Dotazník byl rozdán 961 podpořeným osobám - účastníkům kurzů (seminářư a exkurzí). Dle pravidel počítání podpořených osob se osoba, která navštívila dva nebo více kurzů započítávala opakovaně.

K vyhodnocování bylo tedy získáno 757 vyplněných dotazníků. Dotazníky byly přepisovány do Microsoft Excelu a v tomto programu také vyhodnocovány obvyklými metodami (metoda popisné analýzy dat). Z respondentů bylo 85 mužů, ostatní byly ženy. "Tvrdá data“ byla doplněna o komentáře získané osobní zkušeností a rozhovory s účastníky, lektory a s vedoucími pracovníky projektu.

\section{Stručný popis realizace projektu, výsledky a zkušenosti}

\section{Oblast záj mu}

Nosným tématem projektu bylo zvoleno téma environmentální výchovy a vzdělávání. Toto téma má pro řešitele pozitiva i negativa. Pozitivem je, že patří ve výzvách $\mathrm{k}$ často jmenovaným a podporovaný tématům CŽV. Na druhou stranu ale v České republice existuje Sít středisek environmentální výchovy (Pavučina), jejíž členská střediska (amiž bychom popírali jejich přínos v oboru) tvoří významnou konkurenci sobě navzájem a především řešitelům z jiných pracovišt́. Tato skutečnost byla $v$ př́pravě projektu brána $v$ potaz a záměrně byla volena taková témata a takové cesty jejich realizace, která v nabídce středisek environmentální výchovy učitelé nenaleznou.

Tato témata byla vytyčena výzkumem Bílá místa EVVO v ČR (Jančaříková, 2008). Nabídka projektu Alma mater Studiorum tedy nekonkurovala, ale doplňovala nabídku Středisek environmentální výchovy, především tzv. Dvěstěpadesátku (Školení koordinátorů EVVO). Spojujícím prvkem byl dưraz na výuku v terénu a na hledání propojení v předmětech s EVVO obvykle nepropojovaných (VV, český jazyk, matematika aj.) a také poskytnutí nabídky učitelé všech věkových kategorií (od učitelek MŠ po učitele SŠ a gymnázií).

\section{Výstupy projektu}

V rámci projektu bylo po domluvě s lektory vytvořeno 22 kurzů (15 seminářů a 7 exkurzí). Každý kurz byl akreditován MŠMT. A ke každému kurzu byla vytvořena metodické příručka. Anotace kurzů a všechny metodické příručky jsou zveřejněny na webových stránkách projektu http://almamater.cuni.cz.

Kurzy probíhaly celoročně, s menší frekvencí v adventu a v prázdninových měsících.

\section{Řešitelský tým a prostorové zázemí}

Řešitelský tým byl tvořen převážně pracovníky Pedagogické fakulty Univerzity Karlovy, dlouholetými aktéry Centra environmentálního vzdělávání a výchovy (CEVV).

To s sebou přineslo celou řadu pozitiv. Největší z nich byla odbornost. Všichni řešitelé i lektoři se totiž tématem zabývají řadu let. Pedagogická fakulta v Praze je environmentálnímu vzdělávání a výchově otevřena již celá desetiletí. Krátce po sametové revoluci bylo na PedF založeno RNDr. Evou Liškovou, CSc. (mimochodem nejstarší lektorkou našeho projektu). Centrum environmentálního vzdělávání a výchovy propojuje pracovníky různých 
kateder se zájmem o environmentální problematiku. Existence Centra a zkušenosti pracovníků z různých kateder bylo pro realizaci projektu skvělým zázemím. Naopak finanční prostředky přinesly nejen motivační prvek pro zaměstnance, ale také možnost použít pro realizaci projektu moderní technické a laboratorní vybavení. Neoddělitelnou součástí řešitelského týmu byli profesionální administrativní pracovníci, protože administrativa ESF projektů je složitá.

\section{Účastníci}

\section{Komunikace s účastníky}

Účastníci se do nich mohli hlásit jednak telefonicky a prostřednictvím e-mailu, ale také se mohli do kurzů hlásit on-line přihláškou, která byla umístěna na webových stránkách projektu. Během celého projektu probíhala intenzivní komunikace s potenciálními účastníky. Díky tomu mohli lektoři vycházet vstříc potřebám účastníkům - semináře byly konány např. o podzimních prázdninách apod., čili ve dnech, kdy neprobíhala výuka a nebylo nutné zajištovat suplování. Nebo - na žádost ředitelů škol - byly realizovány semináře prímo na školách - často dva paralelně (jeden pro učitele prvního stupně, druhý pro učitele druhého stupně).

\section{Počet a složení účastníků.}

Jak již bylo výše zmíněno, bylo podpořeno 965 pedagogických pracovníků (tedy o 165 více, než se řešitelé projektu zavázali podpořit).

\section{Z toho}

a) učitelů v MŠ $16 \%$,

b) učitelů na 1 . stupni ZŠ $26 \%$,

c) učitelů na 2 . stupni ZŠ $39 \%$,

d) učitelů na gymnáziu $4 \%$,

e) učitelů na SŠ $6 \%$,

f) jiných pedagogických pracovníků $16 \%$.

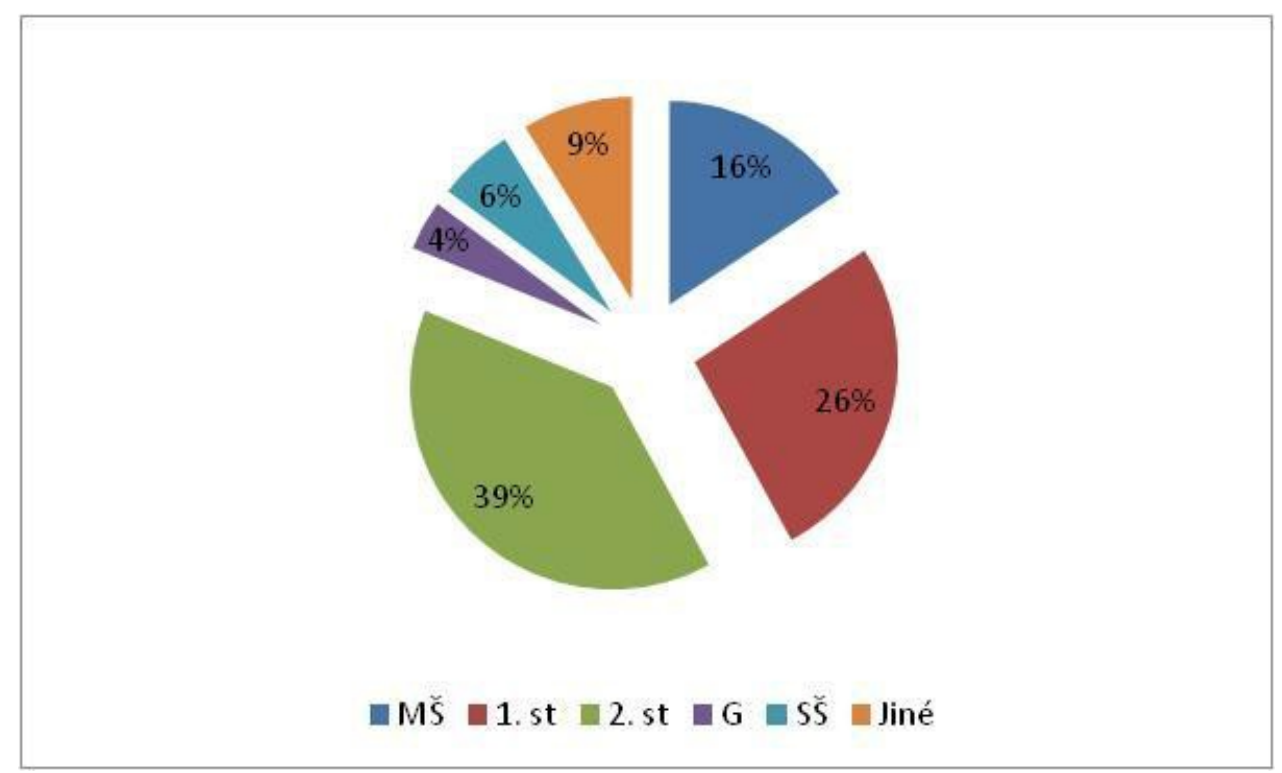




\section{Spokojenost účastníků}

Otázka spokojenosti byla pro nás natolik důležitá, že jsme se na ni dotazovali dvakrát. Jednak otázkou na spokojenost („Nejvíce jsem spokojen ..." a zároveň otázkou na nespokojenost „Nejméně jsem spokojen...“.

Na otázku "Nejvíce jsem spokojen(-a) ... “ respondenti odpovídali takto:
a) s lektorem $32 \%$,
b) se studijními materiály k danému kurzu 13\%,
c) s webovými stránkami projektu $3 \%$,
d) s místem realizace $8 \%$,
e) s organizací kurzu $9 \%$,
f) s pohoštěním $4 \%$,
g) se vším $31 \%$.

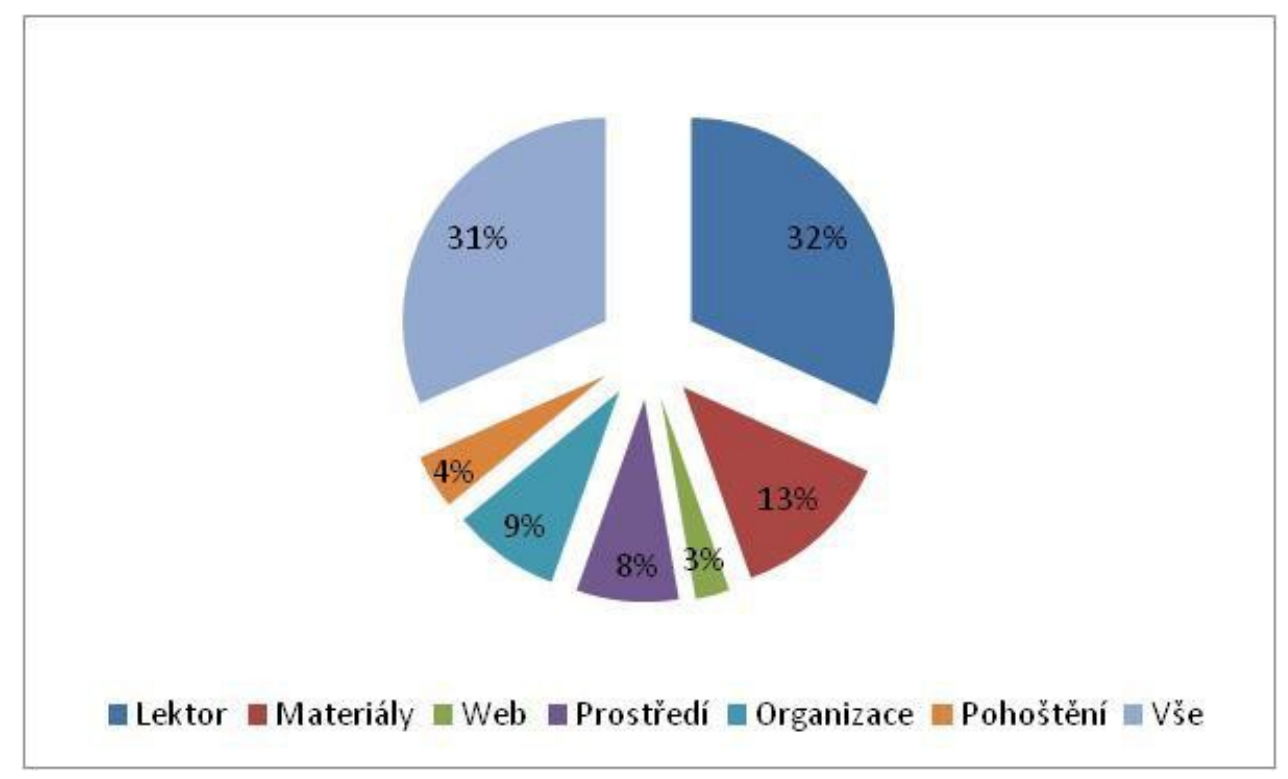

V dotaznících účastníci chválili opakovaně výběr lektorů.

Na otázku "Nejméně jsem spokojen (-a)...“ respondenti v naprosté většině př́padů znovu opakovali svou spokojenost ( $89 \%)$. Několik málo respondentů ( 1 - 2 osoby) projevili nespokojenost $\mathrm{s}$
a) s lektorem daného kurzu,
b) se studijními materiály,
c) s webovými stránkami projektu,
d) s místem realizace,
e) s organizací,
f) s pohoštěním. 


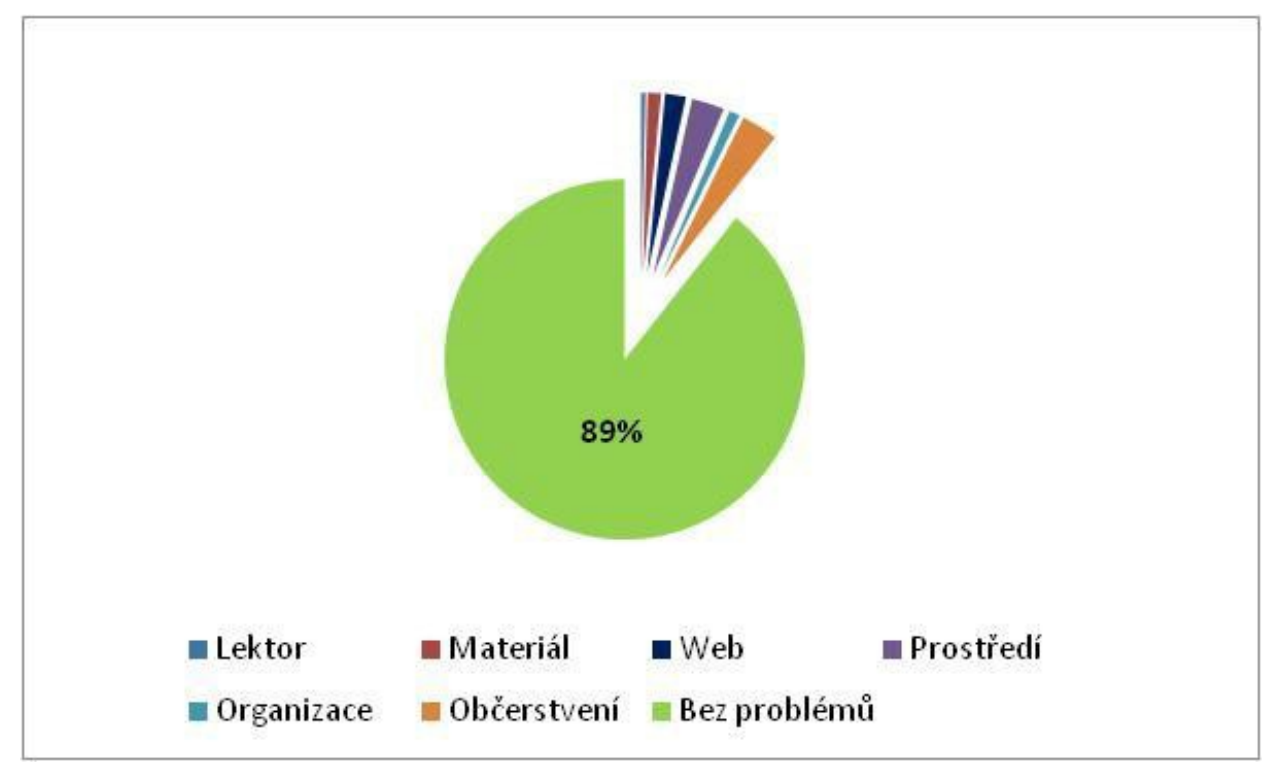

Informace pro udržitelnost

\section{Ochota účastnit se kurzu, i kdyby byl placený}

Díky podpoře z ESF byly veškeré kurzy pro účastníky zdarma. Navíc účastníci dostávali zdarma metodickou př́ručku, blok, propagační propisku a občerstvení. Na otázku „Účastnili byste se kurzu, i kdyby byl placený?" odpovídali respondenti takto:
a) rozhodně ano $24 \%$,
b) spíše ano $45 \%$,
c) nevím 19\%,
d) spíše ne $11 \%$
e) rozhodně ne $1 \%$.

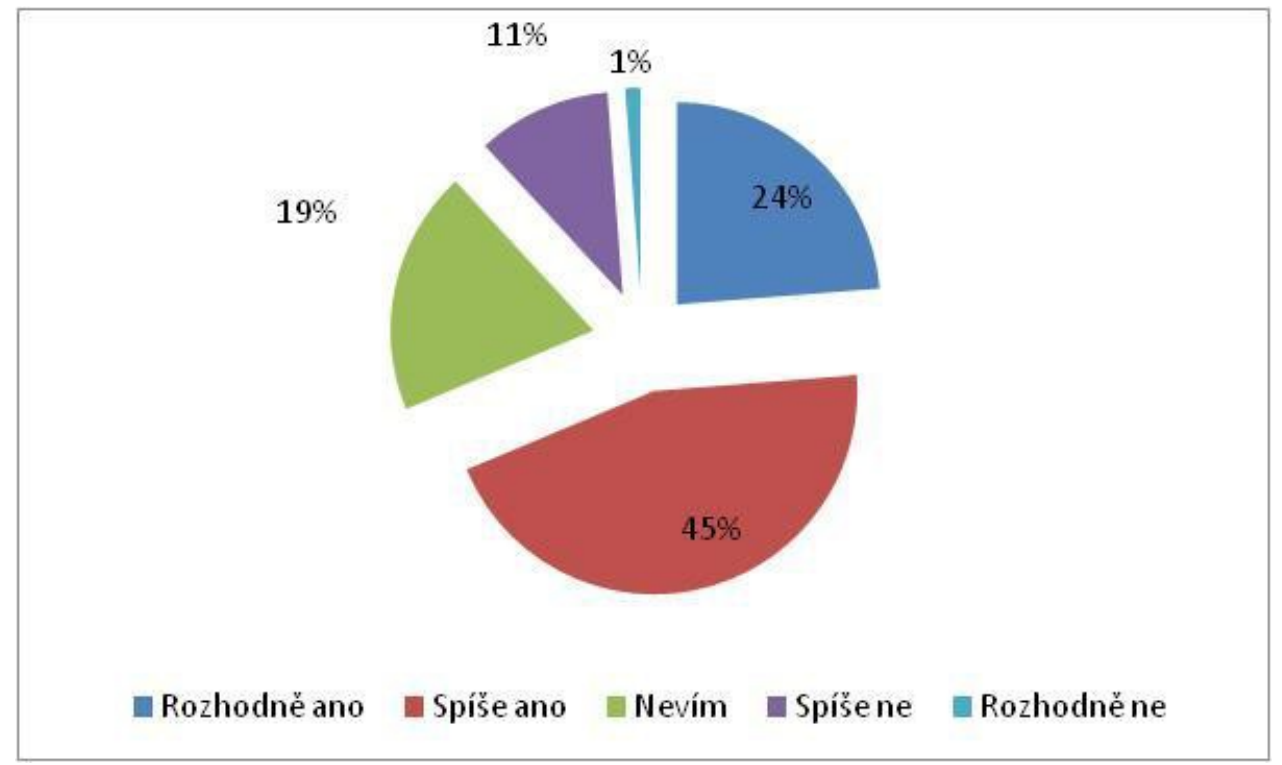




\section{Důležité informace pro propagaci dalších kurzů cžv}

Pro potřeby propagace dalších kurzů jsme se respondentů dotazovali také, kde či od koho se o kurzech Alma mater dozvěděli.
a) od ředitele /ředitelky školy $18 \%$,
b) od kolegy (kolegyně) $17 \%$,
c) na Pedagogické fakultě $17 \%$,
d) z webových stránek projektu $15 \%$,
e) prostřednictvím e-mailové propagace $20 \%$,
f) od lektorů projektu Almy mater $10 \%$,
g) od dalších pracovníků zapojených v projektu Alma mater $2 \%$,
h) jinde $1 \%$.

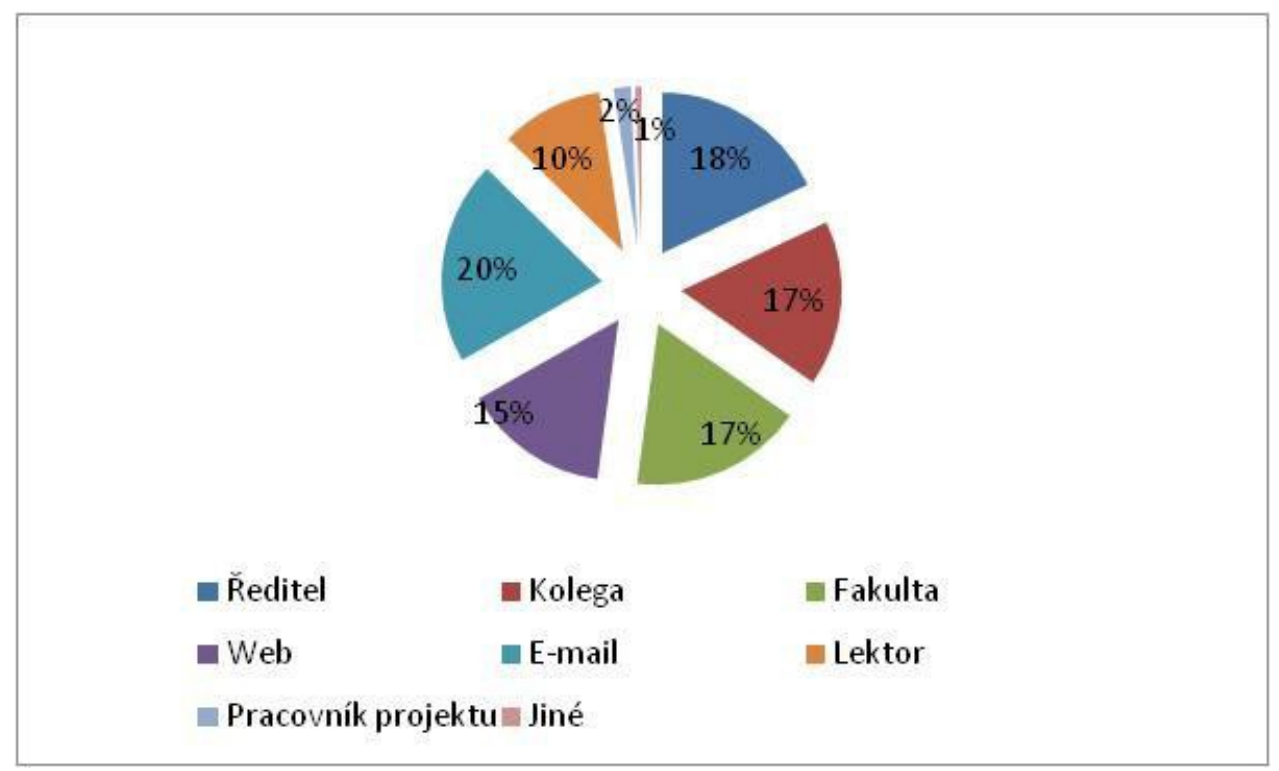

\section{Diskuse}

Nabízené kurzy byly navštěvovány učiteli všech věkových kategorií i volnočasovými pedagogickými pracovníky relativně rovnoměrně. Před vyhodnocením dat bylo očekáváno, že nejvíce účastníků bude z řad učitelek (a učitelů) mateřských škol, a to proto, že pro tuto cílovou skupinu donedávna nebyla dostatečná nabídka kurzů cžv. Tento předpoklad se nepotvrdil, více účastníků bylo z řad učitelů zš. Možná se na této skutečnosti projevilo zavedení školení pro koordinátory EVVO v MŠ, které bylo zahájeno přibližně ve stejnou dobu jako náš projekt.

Pozitivně Ize hodnotit relativně vysokou účast učitelů ze SŠ a gymnázií - v cžv tradičně nejméně angažovanou skupinu.

Disproporce mezi počtem účastníků a účastnic Ize vysvětlit samozřejmě disproporcí mezi učiteli a učitelkami v českém školství. Dále se nabízejí další vysvětlení, např. úvaha, že učitelé - muži jsou natolik sebevědomí, že se domnívají, že kurzy cžv nepotřebují. Ty by ovšem bylo nutné dále ověřovat. 
Za významnou musíme považovat informaci, že by se více než polovina účastníků kurzu pravděpodobně účastnila, i kdyby byl placený. V příších letech bude podpora z EU do českého cžv stále menší. Odpovědi zde získané poskytují naději, že cžv bude pokračovat navzdory menší podpoře - čeští učitelé si vzdělávání váží a stojí o něj.

Otázka na zdroj informace o projektu nepřinesla žádaný výsledek (jeden nejdůležitější způsob, jak učitele oslovovat). Účastníci se o existenci projektu dovídali poměrně rovnoměrně všemi zjištovanými způsoby. Nezbývá tedy než pokračovat $v$ různorodé propagaci projektů, využívat veškeré možné kanály.

\section{Závěr}

Projekt Alma mater Studiorum naplnil (a mírně překročil) vytčené cíle co se týká počtu podpořených osob i počtu produktů (metodických příruček a akreditovaných kurzů). Z vysoké spokojenosti respondentů a z jejich ochoty zúčastnit se placených kurzů Ize vyvodit, že byl př́nosem i pro pedagogické pracovníky.

V několika bodech se pokusme shrnout naše zjištění a následná doporučení: aby byl projekt úspěšný, je vhodné, aby

a) vzdělávací oblast byla vybrána s rozvahou a dílčí témata výzkumně (zjištování potřeb a zájmu potencionálních účastníků, rozbor konkurenčních nabídek aj.).

b) řešitelský tým byl dobře vybrán - jak s ohledem na odbornost a profesionalitu, tak i na mezilidské vztahy a entuziasmus, v řešitelském týmu by neměl chybět manažer se zkušeností s řešením projektů ze stejných fondů,

c) propagace projektu byla vedena různými způsoby - žádný z nich nebyl neúčinný, každý z nich přivedl účastníky.

\section{Literatura a zdroje}

- Bočková, V. Celoživotní vzdělávání - výzva nebo povinnost? Olomouc: Andragogé, 2000. ISBN 80-244-0155-X.

- Jančaříková, K. Environmentální výchova na prvním stupni ZŠ. Praha, 2008. 107 s. UK, PedF. Vedoucí dizertační práce RNDr. Vasilis Teodoridis, Ph.D.

- Kohnová, J. Další vzdělávání učitelů a jejich profesní rozvoj. Praha: Univerzita Karlova v Praze - pedagogická fakulta, 2004, 183 s., ISBN 80-7290-148-6.

- Palán, Z. Další vzdělávání ve světě změn. 1. vyd. Praha : Univerzita Jana Amose Komenského Praha, 2007. ISBN 978-80-86723-31-0.

\section{Důležité odkazy}

- Alma mater Studiorum - webové stránky: http://almamater.cuni.cz 
- Dlouhodobý záměr vzdělávání a rozvoje vzdělávací soustavy České republiky 2007. Dostupné na WWW: https://www.databaze-strategie.cz/cz/msmt/strategie/dlouhodoby-zamer-vzdelavani-a-rozvoje-vzdelavaci-soustavy-ceske-republiky-na-obdobi2015-2020

PhDr. Kateřina Jančaříková, Ph.D., vedoucí Centra environmentálního vzdělávání a výchovy, katedra biologie a environmentálních studií PedF UK v Praze 